\title{
ELECTRONIC BANKING, ITS USE AND SAFETY. ARE THERE DIFFERENCES IN THE ACCESS OF BANK CUSTOMERS BY GENDER, EDUCATION AND AGE?
}

\author{
Jaroslav BELÁS, ${ }^{15}$ Michal KORAUŠ,${ }^{16}$ Lenka GABČOVÁ ${ }^{17}$
}

\begin{abstract}
Electronic banking is an important area of banking activities, under which the commercial banks try to retain existing clients or attract new customers through a better quality of service and decrease in prices of these services. The aim of the article was to examine selected attributes of security and the use of electronic banking and quantify differences in approach of the bank customers by gender, education and age. Our research confirmed that the dominant part of banking customers use electronic access when managing their personal finances. We found out that there are some differences in the approach of the bank customers in terms of their education. The customers with higher education to a greater extent and more intensively use electronic banking. In the safety area, we did not find any significant differences between banking clients by gender, education and age. The only exception is the finding that clients up to 35 years are significantly more confident in the use of electronic banking through public networks.
\end{abstract}

\section{KEY WORDS}

Commercial banks, electronic banking, the use of electronic banking, electronic banking security, gender, education, age

\section{JEL CLASSIFICATION}

G21

\section{INTRODUCTION}

The rapid development of information and communication technologies in recent years has triggered a wave of innovation in the banking sector and led to the emergence of new distribution channels, electronic banking (e-banking), and it represents extensive opportunities in the way of organizing of development of financial products for the bank, as well as the distribution of these products to clients through the Internet. Better technology, more distribution channels and greater

\footnotetext{
15 Correspondence address: prof. Ing. Jaroslav Belás, PhD., Department of Enterprise Economics, Faculty of Management and Economics, Tomas Bata University in Zlin, Mostní 5139, 76001 Zlin, Czech Republic; email: belas111@gmail.com

${ }^{16}$ Correspondence address: Ing. Michal Korauš, Pan-European University, Faculty of Economics and Business, Tematinska 10, 85105 Bratislava, Slovak Republic, e-mail: michal.koraus@gmail.com

${ }^{17}$ Correspondence address: Ing. Lenka Gabčová, Department of Enterprise Economics, Faculty of Management and Economics, Tomas Bata University in Zlin, Mostní 5139, 76001 Zlin, Czech Republic; email: gabcova@ fame.utb.cz
} 
flexibility brings more significant effects in terms of quality of banking products and ultimately it means a higher degree of satisfaction of customer needs (Sysáková and Šlahor, 2010).

Electronic banking is the most advanced and most dynamically developing direct form of communication between the bank and the client in the form of electronic connection where the client does not come into personal contact with employees of the bank. It uses communication media such as a personal computer with a modem, telephone, mobile phone, etc., so it carries out operations from its terminal or other publicly available technical equipment (Tkáčová et al., 2009).

The use of these new distribution channels highlighted the important role of banking security, because the environment is more vulnerable to system attacks (Koskosas, 2011; Dhillon and Torkzadeh, 2006). According to Fatima (2011) delivering of financial services over public networks such as the Internet is bringing about a fundamental shift in the financial services industry. The providers of Internet banking services must be more responsive towards security requirements. Security threats can affect a financial institution through numerous vulnerabilities. No single control or security device can adequately protect a system connected to a public network. Many problems concerning the security of transactions are the result of unprotected data being sent between clients and servers.

This article discusses the use and safety of electronic banking within defined social groups.

\section{ELECTRONIC BANKING, ADVANTAGES AND DISADVANTAGES, USE AND SAFETY}

According to Polouček et al. (2013), electronic banking can be defined as the provision of banking products and services to clients by means of electronic ways.

Advantages and disadvantages accruing for interested parties in case of the use of electronic banking can be defined as follows.

The Advantages of electronic means of communication for the client: increased competition is usually transformed into improved quality of services and lower fees for traditional banking services, the client does not need to physically visit the bank, which means, increase of comfort, significantly better availability of banking products and services, saving time and costs compared to physical presence in the bank, fast and unlimited access 24 hours a day.

The Advantages of electronic means of communication for the bank: lower costs for the Bank (saving capital and operating costs), and by transferring simple banking transactions to a client has opened a room devoted to consultancy for more demanding banking products.

Disadvantages of electronic means of communication for the bank: high costs of acquisition and operation of the electronic banking system, possible problems of unambiguous identification of a client without personal contact, the potential loss of sales opportunities compared with personal contacts, high demands for safety of communication at all levels.

Disadvantages of electronic means of communication for the client: the need for appropriate technical equipment and minimal knowledge of the control of technical equipment. (more details: Belás et al., 2010)

According to Koskosas (2011) electronic banking provides tremendous benefits for bank customers in terms of simplicity and transaction costs, but it also presents new challenges for banks in the field 
of financial systems, where the design and implementation are necessary to consider safety measures and controls.

Currently banks are intensively using internet technologies and offer customers their banking services through the Internet. Internet banking can be defined as the provision of banking services through a computer network (the internet). It is the most important form of electronic banking at present.

Clients who use internet banking have continuous access to their accounts, at any time and space they may carry out money transfers between accounts, view their bank statements for transactions or to pay their bills and perform other banking transactions electronically through the website of the bank (Yoon and Steege, 2013; Yoona and Occeña, 2014).

Internet banking has created an alternative to visits of the banking branches and from the establishment of a global computer network its use just continues to grow. While in 1993 the Internet was used only by less than 15 million users ( $0.3 \%$ of the world population), in 2014 their number was already around three billion users (40.4\% of the world population) (Internet live stats, 2014).

In Slovakia, the Internet users increase was slower than the worldwide trend, but Slovakia now belongs among the countries with the highest penetration of the Internet in the world. In 2014 the internet banking was used by $83 \%$ of the population (Internet live stats, 2014).

The concept of customer-perceived security is closely linked to the use of electronic banking and it has been shown that it influences the behavior and attitudes of bank customers (Grabner-Krauter and Faullant, 2008). According to Lee (2009), Featherman and Pavlou (2003), the perceived lack of security, defined as the potential loss due to fraud or threat to security through Internet banking. Therefore, Kruck, Gotts, Moghadami, Broom, and Forcht (2002), Flavián and Guinalíu (2006) consider security and privacy as two main prerequisites for trust and confidence in electronic banking (e-banking).

According to Nochai and Nochai (2013) the quality of online banking can significantly enhance customer satisfaction by offering access to a range of financial transactions.

Chu, Lee, Chao (2012) have tested the relationships between service quality, customer satisfaction, customer trust and loyalty in electronic banking. The authors state that if e-banks want to develop strong relationships with their customers, generally this will happen automatically through the provision of excellent e-service quality; e-service quality may even have a direct role in maintaining the customer trust, satisfaction, and loyalty. E-service quality was found to have a strong positive impact on e-loyalty, along with customer satisfaction and customer trust. Quantification of individual bonds is presented in Pic.1. 


\section{Figure 1 Links between different variables}

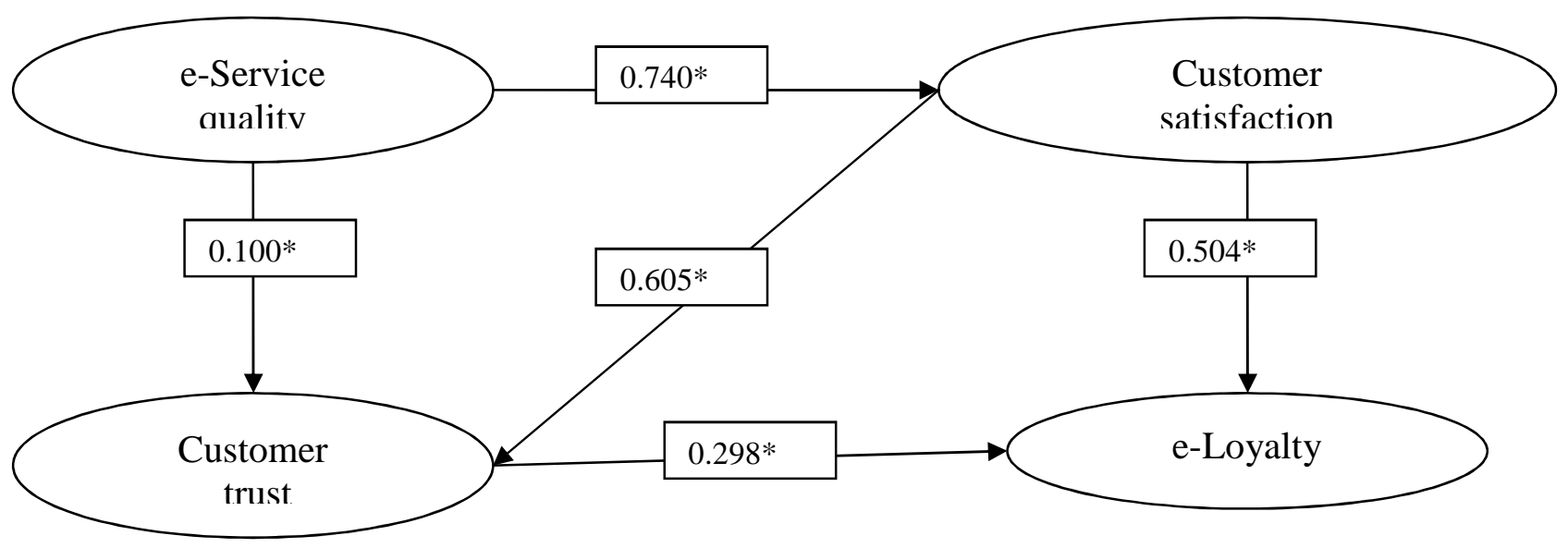

(Source: Chu, Lee, and Chao, 2012)

Note: * Correlation coefficient

Marimon, Yaya, Fa (2012) reported that in electronic business there exists a direct relationship between the quality of services (perceived value) and customer loyalty. Efficiency is the most important factor, which generates customer loyalty in the user, the other two factors (system availability and ensuring of privacy) are less important. According to the authors, the effectiveness means that the bank's customer can easily find what it needs, operations are performed quickly, information is well-organized, access to the web is fast, and it is easy to be used as well.

Figure 2 shows the important links between different variables and their quantification.

\section{Figure 2 Significant links between different variables and their quantification}

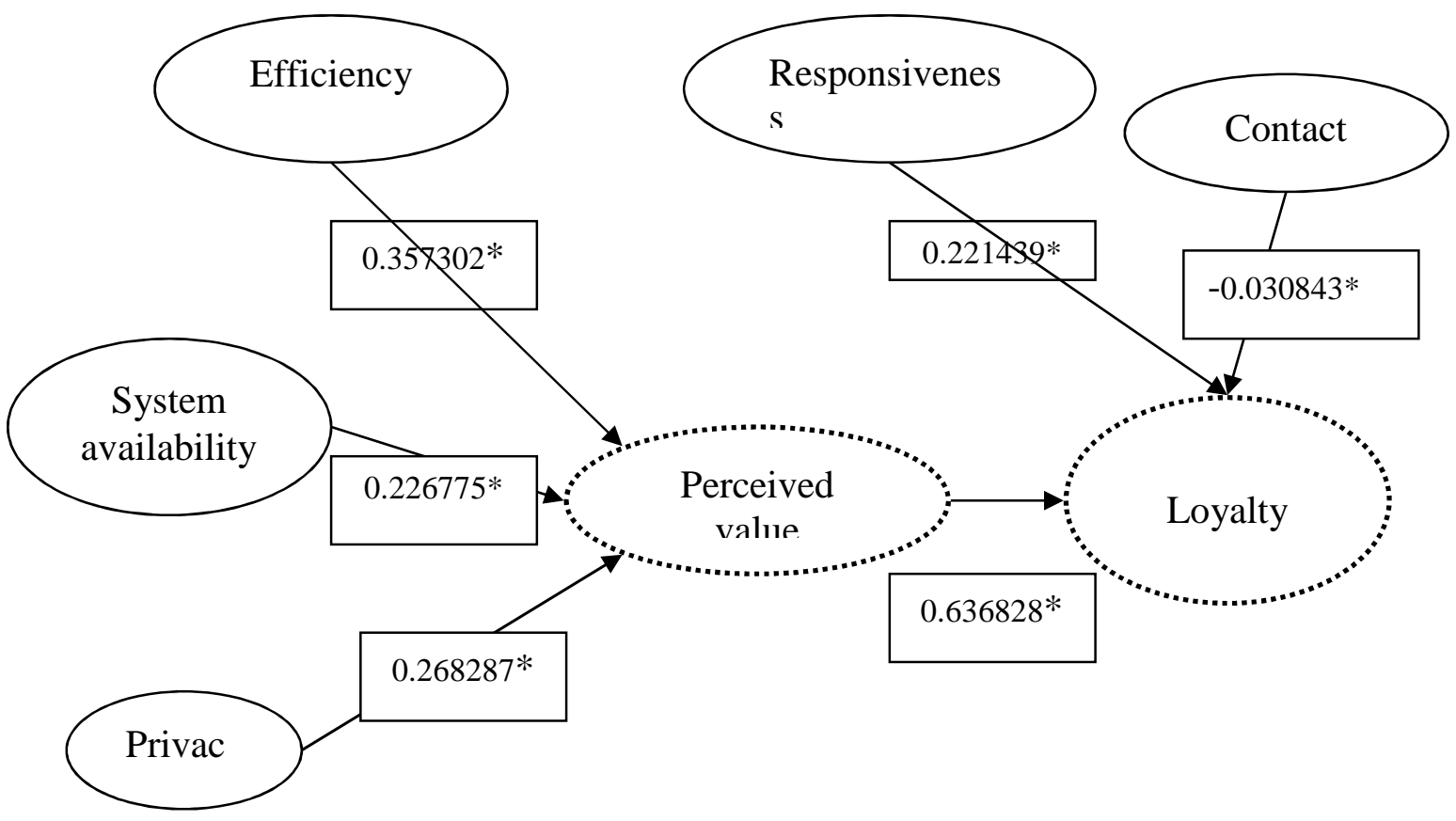

(Source: Marimon, Yaya, and Fa, 2012)

Note: * Path coefficient

Chen, Hsiao, and Hwang (2012) reported that IBCS (Internet banking customer satisfaction) model is a model that consists of six major components: content, accuracy, format, ease of use, timeliness 
and safety. According to the results of this study IBCS model was significantly emphasizing that consumers are sensitive to Internet safety (safety technology, consumer confidence in internet services).

There are a continuously growing number of customers who use Internet banking because of its convenience. But the security and privacy of Information may be one of the biggest concerns to the Online Banking users. The problem with Online banking applications is that they send data directly to customer in plain text form compromising with security. The solutions to the security issues require the use of software-based solutions that involve the use of encryption algorithms. For this we propose a challenge-based/response-based short-time password authentication methods using Symmetric cryptography in combination with Software Security model (Shazmeen and Prasad, 2012).

Hoffmann and Birnbrich (2012) examined the security attributes of electronic banking. According to the authors, security is a fundamental and increasingly important issue in today's banking industry. Fraud prevention has become a central concern to banks, customers, and public policy makers. Banking fraud hurts both banks and their customers.

Older customers indicate to be more familiar with and have a better knowledge about their banks' fraud prevention measures than younger ones, while the positive effects of knowledge ability on customer relationship quality are significantly lower for the older age group. These findings suggest that perceptions of being well informed and knowledgeable may make older customers more skeptical about the anti-fraud measures employed by their bank than younger customers. Fraud prevention is a crucial aspect in bank relationship for customers across all education and income levels (Hoffmann and Birnbrich, 2012).

\section{RESEARCH OBJECTIVE, METHODOLOGY AND DATA}

The aim of this article was to examine the selected attributes of security and the use of electronic banking and quantify differences in the approach of clients by gender, education and age.

Within the research we have conducted a questionnaire survey in the Slovak Republic in 2015 on a sample of 321 respondents, of which $61.37 \%$ were male and $38.63 \%$ were women. The education level of respondents was as follows: most respondents $(67.60 \%)$ had university education, $27.41 \%$ of respondents had secondary education and $4.98 \%$ reported that they have a basic education only.

The research was conducted by a random selection. The questionnaire was freely accessible at http://www.iankety.sk/dotaznik/327968727/.

In our research $51.71 \%$ of respondents were aged $18-35$ years and $48.29 \%$ of the respondents were aged over 35 years. In our research, we set two fundamental scientific hypotheses. In determining the assumptions we have used findings of cited authors and proceeded with estimation techniques based on their own research:

H1: The use of electronic banking by defined social groups of banking clients is not the same.

H1a: Men, university educated clients and younger customers using electronic banking more in general.

H1b: Men, university educated clients and younger customers using electronic banking more often.

$\mathrm{H} 2$ : There are differences in opinions within the bank customers in terms of identified social groups to the security attributes of electronic banking. 
H2a: Women customers with lower education (not universities), and older clients have a lower level of trust in the security of electronic banking.

$\mathrm{H} 2 \mathrm{~b}$ : Women, customers with lower education (not universities), and older clients are less likely to connect to the electronic banking services through public networks.

H2c: Women, customers with lower education (not universities), and older clients are less likely to follow current trends in electronic banking.

The validity of each hypothesis was verified by us through the Pearson statistics. This method allows us to quantify statistically significant differences within the defined sets of respondents. Description of Chi - square test of a good correlation is according to Řezánková (2007) approximates as follows. We test the hypothesis $\mathrm{H}_{0:} \pi_{\mathrm{i}}=\pi_{\mathrm{i}}, 0$, where $\mathrm{i}=1,2, \ldots, \mathrm{K}$ (K the number of categories) a $\sum \pi \mathrm{i}_{, 0}=1$, against the alternative hypothesis $\mathrm{H}_{1}: \mathrm{H}_{0}$ does not apply. Unless the constants $\pi_{\mathrm{i}, ~}, 0$ are equal, then the null hypothesis could be expressed as $\mathrm{H}_{0}: \pi_{1}=\pi_{2}=\ldots=\pi_{\mathrm{k}}$. For $\mathrm{n} \pi_{\mathrm{i}, 0}$ $\geq 5$ the Chi-square statistics given by the relation is being used:

$\chi^{2} \sum_{i=1}^{K} \frac{(n i-n \pi i, 0) 2}{n \pi i, 0}$

where: $n \pi_{i, 0}$ is the theoretical (expected) occupancy of the $\mathrm{i}$-th category in the selection of the range of $\mathrm{n}$. This random variable has provided the true hypothesis $\mathrm{H}_{0}$, chi - square separation with $(\mathrm{K}-1)$ degree of freedom, i.e. $\chi^{2 \sim} \chi^{2[\mathrm{k}-1]}$. Calculated value of the test criterion $\chi^{2}$ is therefore could be compared with quintile $\chi_{1-\alpha}^{2}[\mathrm{~K}-1]$

The validity of each hypothesis, was verified by us through the p-value on a significance level of alpha $=0,5$. Also the calculated value is greater than 0.05 , and $\mathrm{H} 0$ is true. If the calculated p-value is less than 0,05 , we did not confirm the validity of $\mathrm{H} 0$ and thus the validity of the hypothesis $\mathrm{H} 1$ can be confirmed.

When calculating the p-values in the chi-square method we have used freely accessible calculator available at: http://www.socscistatistics.com/tests/chisquare2/Default2.aspx For the detection of statistically significant differences in the individual answers to the questions we have used freely accessible calculator for calculating the Z-Test available on: http://www.socscistatistics.com/tests/ztest/Default2.aspx.).

\section{RESULTS AND DISCUSSION}

In Table 1 there are shown the results of research on the use of electronic banking. 
Table 1 Quantitative evaluation of individual social groups in the use of electronic means of payment

\begin{tabular}{|l|r|r|r|r|r|r|r|}
\hline $\begin{array}{l}\text { Do you use } \\
\text { electronic } \\
\text { forms of } \\
\text { payment in } \\
\text { banking? }\end{array}$ & $\begin{array}{c}\text { Men } \\
\text { Count: } \\
197\end{array}$ & $\begin{array}{c}\text { Women } \\
\text { Count: } \\
124\end{array}$ & $\begin{array}{c}\text { Higher } \\
\text { Educated } \\
\text { Count: } \\
217\end{array}$ & $\begin{array}{l}\text { Others } \\
\text { Count } \\
: 104\end{array}$ & $\begin{array}{c}\text { Under 35 } \\
\text { years } \\
\text { Count: } \\
166\end{array}$ & $\begin{array}{c}\text { Over } \\
35 \\
\text { years } \\
\text { Count: } \\
155\end{array}$ & $\begin{array}{c}\text { p-value } \\
\text { Z-test } \\
\text { Men/Women } \\
\text { HE/Others } \\
\text { 35-/35+ }\end{array}$ \\
\hline $\begin{array}{l}\text { 1. Yes } \\
\text { share in \% } \\
\text { share in \% } \\
\text { total=91.90 }\end{array}$ & 91.37 & 92.74 & $\mathbf{9 4 . 9 3}$ & 85.58 & 94.58 & $\mathbf{8 9 . 0 3}$ & 0.6599 \\
\hline 2. No & & & & & & & $\mathbf{0 . 0 0 4 1}$ \\
\hline Chi square & 0.1923 & & & 115 & & & \\
p-value & 0.6610 & & $\mathbf{8 . 2 6 4 1}$ & & 3.3122 & & \\
\hline
\end{tabular}

(Source: own research)

The research results have shown that electronic forms of banking in Slovakia are used by more than $90 \%$ of respondents. Within the defined social groups, it was found that the largest share of users of electronic banking in the group of respondents with higher education and the smallest share of users in the group of respondents over 35 years.

The values of test criteria (chi-square and p-value) listed in Table 1 confirmed partial validity of hypothesis H1a. It was found out that there are statistically significant differences in the intensity of use of electronic banking between bank clients with a university degree and customers with other types of education (chi-square $=8.2641 / \mathrm{p}$-value $=0.0040)$. P-value of the Z-test $(0.0041)$ showed that higher education clients significantly more use electronic forms of payment than other customers.

The results of our study are compatible with the findings by Internet Live Stats (2014). For example, Ernst \& Young (2012) stated that $78 \%$ of customers in the Czech Republic control their bank accounts via Internet. It can be assumed that at present the use of internet banking in the Czech Republic is about the same as in Slovakia. These data confirm the enormous growth of internet banking by users around the world.

The quality of electronic banking considerably determines customer satisfaction with the bank. This fact is confirmed by the results of our previous researches. Survey results for reasons of satisfaction in the Czech Republic present the fact that most clients are satisfied with the possibilities of electronic banking (e-banking). The possibility of using of electronic banking (e-banking) as the most important factor in satisfaction was mostly preferred by women than men, the young people up to 30 years and clients with higher education. In the banking sector of Slovakia the most important factor in satisfaction was the possibility of using of e-banking service, the second most important reason for satisfaction was the availability of the bank's branch and the third most important reason for satisfaction was well developed network of ATMs. This research has shown statistically significant differences in individual social groups. The possibility of using of e-banking service is more significant in Slovakia for younger clients and customers with higher education (Belás, Cipovová, and Demjan, 2014). These findings are similar to findings of Nochai and Nochai (2013), Chu, Lee, and Chao (2012), and Marimon, Yaya, and Fa (2012).

In Table 2 there are presented the results of research on the intensity of the use of electronic banking. 
Table 2 The intensity of the use of electronic banking

\begin{tabular}{|l|r|r|r|r|r|r|r|}
\hline $\begin{array}{l}\text { How often do you } \\
\text { use electronic } \\
\text { banking (EB)? }\end{array}$ & Men & Women & $\begin{array}{c}\text { Higher } \\
\text { Education }\end{array}$ & Others & $35-$ & $35+$ & $\begin{array}{c}\text { p-value } \\
\text { M/W } \\
\text { /Others } \\
\text { 35-/35+ }\end{array}$ \\
\hline $\begin{array}{l}\text { 1. Daily } \\
\text { share in \% } \\
\text { share in \% } \\
\text { totally=61.37 }\end{array}$ & 59.90 & 63.71 & $\mathbf{6 5 . 9 0}$ & 51.92 & 65.66 & 56.77 & 0.4965 \\
\hline 2. Once a week & 67 & 38 & 69 & 36 & 50 & 55 & 0.1031 \\
\hline 3. Once a month & 7 & 4 & 5 & 6 & 4 & 7 & \\
\hline 4. Never & 5 & 3 & 0 & 8 & 3 & 5 & \\
\hline $\begin{array}{l}\text { Chi square/ } \\
\text { p-value }\end{array}$ & 0.4715 & & $\mathbf{2 1 . 5 6 3 9}$ & & 3.4219 & & \\
\hline
\end{tabular}

(Source: own research)

In our research, it was found out that up to $65.90 \%$ of Slovakian university graduates banking customers are using electronic banking daily. The average intensity of daily use of electronic banking is relatively high, and this is confirmed by the number of $61.37 \%$.

H1b was partially confirmed, because we found that university education clients significantly more use electronic banking on a daily basis. When compared by gender and age, we did not find any significant differences in daily use of electronic banking.

Within the H1, we assumed that the use of electronic banking by the social groups defined by bank customers is not the same. Our research confirmed partially the validity of hypothesis H1 (clients with higher education to a greater extent and more intensively use electronic banking).

In Table 3 we present the results of research in which the clients evaluated the safety of electronic payments.

Table 3 Security of payments through electronic banking

\begin{tabular}{|l|r|r|r|r|r|r|r|}
\hline $\begin{array}{l}\text { Do you believe } \\
\text { that the payments } \\
\text { through EB are } \\
\text { safe? }\end{array}$ & Men & $\begin{array}{c}\text { Wom } \\
\text { en }\end{array}$ & $\begin{array}{c}\text { Higher } \\
\text { Education }\end{array}$ & Others & $\begin{array}{c}\text { Under } \\
35 \\
\text { years }\end{array}$ & $\begin{array}{c}\text { Over 35 } \\
\text { years }\end{array}$ & \multicolumn{1}{c|}{$\begin{array}{c}\text { p-value } \\
\text { M/W } \\
\text { /Others } \\
\text { 1. Yes }\end{array}$} \\
$\begin{array}{l}\text { share in \% } \\
\text { share in \% } \\
\text { totally=78.19 }\end{array}$ & 80.71 & $\mathbf{7 4 . 1 9}$ & 80.18 & 74.04 & $\mathbf{8 1 . 3 3}$ & 74.84 & 0.2113 \\
\hline 2. No & & & & & & & 0.1585 \\
\hline $\begin{array}{l}\text { Chi square } \\
\text { p-value }\end{array}$ & 0.4689 & 32 & 43 & 27 & 31 & 39 & \\
\hline
\end{tabular}

(Source: own research) 
Confidence in the security of payments via electronic banking varies within the groups surveyed from $74.19 \%$ (women) to the value of $81.33 \%$ (young customers). The overall proportion of clients who believe in the security of electronic payments was at the level of $78.19 \%$.

H2a has not been confirmed, because we did not find any statistically significant differences between social groups of bank customers.

In Table 4 there are presented the results of research on how defined social groups accessing the security attributes, and its whether they connect to the electronic banking in public networks.

Table 4 The use of electronic banking through public networks

\begin{tabular}{|l|r|r|r|r|r|r|r|}
\hline $\begin{array}{l}\text { Do you connect to } \\
\text { the EB through } \\
\text { the public } \\
\text { networks? }\end{array}$ & Men & Women & $\begin{array}{r}\text { Higher } \\
\text { Education }\end{array}$ & Others & $35-$ & $35+$ & $\begin{array}{c}\text { p-value } \\
\text { M/W } \\
\text { HE/Others } \\
35-/ 35+\end{array}$ \\
\hline $\begin{array}{l}\text { 1. Yes } \\
\text { share in \% } \\
\text { share in \% } \\
\text { totally=25.23 }\end{array}$ & 26.40 & 23.39 & 26.27 & 23.08 & $\mathbf{3 1 . 3 3}$ & $\mathbf{1 8 . 7 1}$ & 0.5353 \\
\hline No No & 145 & 95 & 160 & 80 & 114 & 126 & 0.5485 \\
& & & & & & & 0.5353 \\
& & & & & & & $\mathbf{0 . 0 0 9 3}$ \\
\hline $\begin{array}{l}\text { Chi square } \\
\text { p-value }\end{array}$ & 0.3652 & & 0.3793 & & $\mathbf{6 . 7 6 1 9}$ & & \\
\hline
\end{tabular}

(Source: own research)

In our research, we found out that the proportion of clients who use public networks to connect to the Internet was $25.23 \%$, which can be seen as prudential behavior of banking customers in Slovakia.

$\mathrm{H} 2 \mathrm{~b}$ hypothesis was partially confirmed. In our research, we found out that the clients up to 35 years more frequently were using the connection to electronic banking through public networks when compared to older customers ( $\mathrm{p}$-value $=0.0093$ ).

In Table 5 there are presented the results of research on how defined social groups follow current trends in the field of security of electronic banking. 
Table 5 Trends in area of security of cashless payment transactions

\begin{tabular}{|l|r|r|r|r|r|r|r|}
\hline $\begin{array}{l}\text { Do you follow } \\
\text { current trends in } \\
\text { security of EB? }\end{array}$ & Men & Women & $\begin{array}{c}\text { Higher } \\
\text { Education }\end{array}$ & Others & $35-$ & $35+$ & \multicolumn{1}{c|}{$\begin{array}{c}\text { p-value } \\
\text { M/W } \\
\text { HE/Others } \\
35-/ 35+\end{array}$} \\
\hline $\begin{array}{l}\text { 1. Yes } \\
\text { share in \% } \\
\text { share in \% } \\
\text { totally=46.73 }\end{array}$ & 49.24 & 42.74 & $\mathbf{4 9 . 7 7}$ & $\mathbf{4 0 . 3 8}$ & 45.18 & 48.39 & 0.2543 \\
\hline 2. No & 100 & 71 & 109 & 62 & 91 & 80 & 0.1141 \\
& & & & & & & 0.5619 \\
\hline $\begin{array}{l}\text { Chi square } \\
\text { p-value }\end{array}$ & 1.2903 & & 2.4876 & & 0.3310 & & 0.1141 \\
\hline
\end{tabular}

(Source: own research)

According to our research the current trends in the area of electronic banking are monitored by $47 \%$ of bank customers. The largest share of bank clients we have discovered in the segment of university educated respondents $(49.77 \%)$ and the smallest in the group of clients with lower education $(40.38 \%)$.

$\mathrm{H} 2 \mathrm{c}$ has not been confirmed, because we did not find any statistically significant differences between individual social groups.

Within $\mathrm{H} 2$ we assumed that there are differences in the views of the bank customers on security attributes of electronic banking by gender, education and age of the respondents. Our research confirmed the validity of $\mathrm{H} 2$. It was found out that the selected attributes of electronic banking are perceived almost equally by the defined social groups of banking customers.

In our research we have also found out that up to $83.18 \%$ of customers rely on security measures of the bank's online banking and $87.23 \%$ of respondents have a negative experience in hacking attacks or of fraud while utilizing banking services.

According to Furnell, Bryant, and Phippen (2007) the internet represents now the greatest potential threat of attacks on clients of commercial banks. Customers are very well familiar with the internet threats, and they also realize that it is their own obligation to protect against these menaces, even though they have no confidence and knowledge to do so. Via various techniques hackers are trying to get sensitive information from customers of banks with the purpose of abusing them. In recent years, the attacks on electronic banking have increased significantly, while threatening especially bank customers, their personal details and financial resources.

According to Kaspersky Lab company (2014), an organized gang of computer hackers who from the end of 2013 attacked a hundred of banks in 30 countries (Russia, USA, Germany, China, Ukraine, Canada, Hong Kong, Taiwan, Romania, France, Spain, Norway, India, Great Britain, Poland, Pakistan, Nepal, Morocco, Iceland, Ireland, Czech Republic, Switzerland, Brazil, Bulgaria and Australia), has stolen in illegal operations for over a billion US dollars.

These findings are compatible with the conclusions of Chen, Hsiao, and Hwang (2012) and Hoffmann and Birnbrich (2012). 
In this context Fatima (2011) states that financial institutions that offer Internet-based products and services should have reliable and secure methods to authenticate their customers. The level of authentication used by the financial institution should be appropriate to the risks associated with those products and services. Biometric based authentication and identification systems are the new solutions to address the issues of security and privacy. Biometrics is finding its way into all kinds of applications beyond access control. It is expected that more and more information systems/computer networks will be secured with biometrics with the rapid expansion of Internet and Intranet.

The future of electronic banking will be a system where users are able to interact with their banks "worry-free" and banks are operating under one common standard. Most research studies have indicated that the common problem affecting information security and privacy of customers is eservices provider's lack of security control which allows damaging privacy losses. Apart from that, another problem is the subsequent misuse of consumers' confidential information, as in identity theft. These may affect customer's confidence toward online business transaction in a variety of privacy risk assessments by consumers. Current technology allows for secure site design. It is up to the development team to be both proactive and reactive in handling security threats, and it's up to the consumer to be vigilant when doing business online (Omariba, Masese, and Wanyembi, 2012).

\section{CONCLUSION}

Electronic banking represents an important area of business activities of commercial banks. Client access to banking services through electronic distribution channels represents a significant current trend, which determines the satisfaction of bank customers. An important attribute of electronic banking is its safety.

The results of our research have confirmed that the dominant part of bank customers uses electronic access when managing their personal finances. We found out that there are some differences in the approach of bank customers as per their education level. Clients with higher education to a greater extent and more intensively use electronic banking.

In the safety area, we did not find any significant differences between banking clients by gender, education and age. The only exception is the finding that clients up to 35 years are significantly more confident while using electronic banking through public networks.

\section{Acknowledgements}

Authors are thankful to the Internal Grant Agency of FaME TBU No. 005/IGA/FaME/2014: Optimization of Parameters of the Financial Performance of Commercial Banks, for its financial support to carry out this research.

\section{REFERENCES}

Belás, J. et al. (2010) Management komerčných bánk, bankových obchodov a operáciú. Žilina: Georg.

Belás, J., Cipovová, E., Demjan, V. (2014) Current trends in area of satisfaction of banks'clients in the Czech Republic and Slovakia. Transformation in Business \& Economics, Vol. 13, No 3(33), pp. $219-234$.

Dhillon, G., Torkzadeh, G. (2006) Values-focused assessment of information system security in Organizations. Information Systems Journal, Vol. 16, No. 3, pp. 293 - 314. 
Ernst \& Young. (2012) Nová éra bankovnictví. Čeští klienti chtějí, aby banky vyšly více vstřic jejich potřebám. Retrieved from http://www.ey.com/CZ/cs/Newsroom/News releases/2012_Nova-era-bankovnictvi

Fatima, A. (2011) E-Banking Security Issues - Is There A Solution in Biometrics? Journal of Internet Banking and Commerce, 16(2): 1 - 9

Featherman, M. S., Pavlou, P. A. (2003) Predicting e-services adoption: A perceivedrisk facets perspective. International Journal of Human-Computer Studies, Vol. 59, No. 4, pp. 451 474.

Flavián, C., Guinaliu, M. (2006) Consumer trust, perceived security, and privacy policy: three basic elements of loyalty to a web site. Industrial Management \& Data Systems, Vol. 106, No. 5/6, pp. $601-620$.

Furnell, S., Bryant, P., Phippen, A. (2007) Assessing the Security Perceptions of Personal Internet Users. Computers \& Security, Vol. 26, No. 5, pp. $410-417$.

Grabner-Krauter, S., Faullant, R. (2008) Consumer acceptance of internet banking: the influence of internet trust. International Journal of Bank Marketing, Vol. 26, No. 7, pp. 483 - 504.

Hoffmann, A. O. I., Birnbrich, C. (2012) The impact of fraud prevention on bank-customer relationship. International Journal of Bank Marketing, 30(5): 390 - 407.

Chen, R. F., Hsiao, J. L., Hwang, H. G. (2012). Measuring customer satisfaction of Internet banking in Taiwan: scale development and validation. Total Quality Management, 23(7): 749 - 767.

Chu, P. Y., Lee, G. Y., Chao, Y. (2012) Service quality, customer satisfaction, customer trust, and loyalty in an e-banking context. Social behavior and personality, 40(8): $1271-1284$.

Internet live stats. (2014) Internet Users. [online] [cit: 2015-7-13] Retrieved from http://www.internetlivestats.com/internet-users/

Kaspersky Lab (2014) The Great Bank Robbery: Carbanak cybergang steals \$1bn from 100 financial institutions worldwide. Retrieved from http://www.kaspersky.com/about/news/virus/2015/Carbanak-cybergang-steals-1-bnUSD-from-100-financial-institutions-worldwide

Koskosas, I. (2011) E-banking security: A communication perspective in Risk management. Palgrave Macmillan, Vol. 13, pp. 81 - 99.

Kruck, S. E., Gottovi, D., Moghadami, F., Broom, R., Forcht, K. A. (2002) Protecting personal privacy on the internet. Information Management \& Computer Security, Vol. 10, No. 2, pp. $77-84$.

Lee, M. (2009) Factors influencing the adoption of Internet banking: An integration of TAM and TPB with perceived risk and perceived benefit. Electronic Commerce Research and Applications, Vol. 8, No. 3, pp. $130-141$.

Marimon, F., Yaya, L. H. P., Fa, M. C. (2012) Impact of e-Quality and service recovery on loyalty: A study of e-banking in Spain. Total Quality Management, 23(7): 769 - 787.

Nochai, R., Nochai, T. (2013) The impact of Internet Banking Service on Customer Satisfaction on Thailand: A Case Study in Bangkok. International Journal of Humanities nad Management Sciences, 10(1): 2320 - 2344.

Omariba, Z.B., Masese, N. B., Wanyembi, G. (2012) Security and privacy of electronic banking. International Journal of Computer Science Issues, 9(3): 432 - 446.

Polouček, S. a kol. (2013) Bankovnictví. 2. vydání. Praha: C. H. Beck.

Řezánková, H. (2007) Analýza dat z dotazníkových šetření. 1.vyd. Praha: Professional Publishing.

Shazmeen, S., F., Prasad, S. (2012) A Practical Approach for Secure Internet Banking based on Cryptography. International Journal of Scientific and Research Publications, 2(12): 1 - 6.

Sysáková, V., Šlahor, L. (2010) Peniaze a bankovníctvo. Bratislava : Kartprint.

Yoon, H., Occena, L. (2014) Impacts of customers ' perceptions on internet banking use with a smart phone. Journal of Computer Information Systems, Vol. 54, No. 3, pp. 1 - 9.

Yoon, H. S., Steege, L. M. (2013) Development of a quantitative model of the impact of customers' personality and perceptions on Internet banking use. Computers in Human Behavior, Vol. 29, No. 3, pp. $12-29$. 
Tkáčová, D. et al. (2009) Finančné trhy a bankovníctvo. Žilina: Georg. http://www.socscistatistics.com/tests/chisquare2/Default2.aspx

http://www.socscistatistics.com/tests/ztest/Default2.aspx 